tion, however, differed from that suggested by Dr. Eade. The entire surface of the face, neck, liands, and arms was painted over with the strons acid, not all at the same time, but a fresh portion at each visit. A few seconds after the acid was applied, a piece of blotting-paper was laid on to absorb the excess of acid, after which wet lint was applied, which speedily relieved the smarting sensation caused by the acid. The result of this treatment began on the first appearance of the eruption-viz., that the skin became dry and parchment-like, without any trace of pustulation, while the rest of the body was covered with pustules. It was found that the dryness of the skin where the acid had been applied caused some degree of discomfort, but this was relieved by anointing it with salad oil. After desquamation, there was no trace of mark, and far less than the usual degree of redness. I did not venture to paint more than the exposed parts of the body, fearing ill effects from a too large absorption of the acid. As it was; thera appeared for some days the usual effect of the absorption of the acid-viz., a deep discolouration of the urine, but I feel sure that the febrile disturbance was considerably less than it would have been had the acid not been used.

How far a more extensive painting of the surface would be safe I am unable to say, as the rarity of the epidemic here has afforded me but few cases of a severe nature fur the adoption of this treatment. I incline to think, if due care were taken to remove the excess of acid by the immediate use of an alkali and subsequent washing with warm water, and if a not very large patch were painted at one time, that there would be little risk in dealing with almost the entire surface of the body.

I have sometimes felt disposed to try the application of strong nitric acid, painted on rapidly and instantly neutralised by allialine solution. It would not be painful, unless the skin were broken, and would, I think, undoubtedly have the same result as carbolic acid, without the risk from absorption.

So far as regards disfiguration from small-pox, I am sure that we have in carbolic acid the surest preventive of pitting. I think with Dr. Eade that it also affords a means of diminishing febrile action, and if it is found that the entire body can be subjected to treatment in this way, that it will be also a means of largely diminishing the mortality from small-pox.

Lynn, July 16th, 1878

Your obedient servant JoHN LOWE, M.D.

\section{MEDICAL PRACTICE IN SOUTH AFRICA.} To the Editor of THE LANCET.

SIR,-It may be interesting to some of your correspondents who contemplate practising in South Africa to know that there are almost always a number of district surgeoncies vacant in that colony. The pay of a district surgeon is $£ 75$ a year, and, with allowances and extras, generally amounts to about $\$ 100$ per annum. If the candidate for practice can select a district surgeoncy in a part of the country where there is fair scope for private practice, he is rather fortunate, as there are some of these appointments in districts where there is little or no private practice, and consequently the appointment, perse, is useless. In the colony there is also a custom of guaranteeing a medical man a given sum-say $£ 500$ a year, so that financial failure is obviated. Midwifery fees are better than in this country, generally ranging from $£ 3$ to $£ 5$, and visiting fees are paid at the rate of $£ 1$ per hour one way, the physician being presumed to travel at the rate of six miles an hour-e. $g$., if a patient resided eighteen miles distant the fee for visiting him would be $\mathscr{E} 3$.

I now speak of up-country practice, as the towns generally are well supplied with medical men. In the upcountry districts generally the roads are very bad, being mere tracks, rarely or never repaired, and travelling is laborious and disagreeable. The journeys are often very long; the writer has been sent for to visit a patient thirtysix miles off, seven miles of this distance being along the dried-up bed of a river. The country in many parts is desertlike, and the mode of life is necessarily of a somewhat primitive character. The population is widely scattered. Nevertheless, many medical men make good incomes, and accumulate money. I am of opinion that the cost of living and drugs is about 25 per cent. more than in England. The climate generally is good, being well adapted for pulmonary complaints, as it is warm and very dry, without being enervating.

29th July, 1878. I am, Sir, yours, \&c., J. G. ThorNLEY, M.D.

\section{PARLIAMENTARY PROCEEDINGS.}

\section{HOUSE OF LORDS.}

Friday, July 26 th.

IDIOTS, ETC. (IRELAND) BILL.

Lord CARLINGFORD moved the second reading of this Bill, which had come up from the Commons, and in doing so said that its ohject was to enable Boards of Guardians in Ireland, with the consent of the Irish Local Government Board, to send pauper idiots to places in which they could be better cared for than they could be in the workhouses.

The Duke of Richmond and Gordors said he did not oppose the second reading, but in comnittee he would move an amendment to remove any difficulty in the power of the Irish Local Government Board to give effect to the recommendations of a committee which had inquired into the subject.

The Bill was read a second time.

\section{HOUSE OF COMMONS. \\ Thursday, July 25th.}

SMALL-POX.

In answer to Dr. Cameron,

Mr. SCLATER-BooTH said he had caused inquiry to be made as to a statement that a man named Carter, since dead of small-pox, was allowed while prostrated by that disease to lie during ten hours in the public road near Hadham-cross. The man applied for medical relief, but the surgeon did not think it was in any sense a serious case, or that the man was suffering from small-pox. On the following day the man was making his way to the workhouse, when he succumbed. The union officers provided suitable covering for him, and supplied him with tea and brandy, before removing him to the workhouse. He was not removed at once because of the danger of infection. It was true that certain children congregated round the patient as he lay in the road, but he had no information as to who they were or where they came from.

$$
\text { Monday, July 29th. }
$$

VACCINATION PROSECUTIONS.

Mr. GouRLEY asked the Secretary of State for the Home Department if he had had his attention called to the treatment of Thomas Bertram, who was sentenced at Sunderland, on the 14th of June, to fourteen days' imprisonment for the non-vaccination of his child; "who was sent to Durham Gaol handeuffed with ordinary criminals, and while there his daily diet consisted of two pints of gruel and $11 \mathrm{lb}$. of bread; that he was denied the use of a mattress on which to sleep, and that his cell door was kept continually locked with the exception of three-quarters of an hour twice a day while out for exercise ;" and if he intended making any alterations in the existing prison regulations.

Mr. Cross said the matter did not rest with the Home Secretary, and he had hoped it would be put right by the passing of a Summary Jurisdiction Bill this session. It had not been found possible, however, to introduce it, but it would be brought on as early as possible next session. $\mathrm{He}$ agreed with the hon. gentleman in regard to the indiscriminate use of handcuffs, and had expressed his opinion very strongly on the matter.

THE MEDICAL ACT AMENDMENT BILL.

In reply to Dr. Playfair and Mr. Mills, Lord G. HAMILTON said : In consequence of the opposition by certain members to this Bill, its chances of becoming law this year daily diminish. My amendments were put upon the notice paper to make clear to the opponents of the Bill the course we intended to take, in the hope that their opposition would be then removed, and until I know the effect of my amendments I am unable to give a definite answer as to the fate of the Bill.

Mr. J. H. WORRALI, M.R.C.S. Eng., has been placed on the Commission of the Peace for Lancashire. 